Studies in African Linguistics

Volume 34, Number 2, 2005

\title{
FOUR WORDLISTS OF EXTINCT CAPE KHOEKHOE FROM THE 18TH CENTURY*
}

\author{
François-Xavier Fauvelle-Aymar \\ Centre National de la Recherche Scientifique (France) \\ French Institute of South Africa (Johannesburg)
}

\begin{abstract}
The Khoekhoe language, a member of the Khoisan family, was widely spoken by Southern Africa pastoralists and hunters-gatherers a few centuries ago. Apart from varieties still spoken in the $20^{\text {th }}$ century (such as Nama in Namibia), very little is known of the dialect spoken by the Cape Khoekhoe. This paper is a critical edition of four manuscript wordlists collected at the end of the $18^{\text {th }}$ century by Robert Jacob Gordon, then commandant of the Dutch garrison at the Cape. These lists refer to several local varieties of the Cape Khoekhoe language, collected just before it became extinct, and display two distinct systems of clicks rendering.
\end{abstract}

When European travelers started to visit the coast of Southern Africa at the end of the 15 th century, they met people who, they said, were "clucking and whistling" like "angry turkeys" (Raven-Hart 1967: 19). It was obviously an allusion to a phonological characteristic of local languages, namely the presence of "clicks" (compound sounds consisting of influxes and effluxes). Such clicks are found in all the languages of the Khoisan family (Greenberg 1966: 66-84), in two linguis-

* My acknowledgment to the staff of the Brenthurst library, and especially to Diana Madden; to Werner Prinsloo, who helped me with the Dutch; to Karim Sadr and Laurent Chauvet, who kindly read and corrected a previous version of this article, and to the editor and the anonymous referees for helping to improve this paper. 
tic isolates of Tanzania which may or may not belong to the same family (Köhler 1981: 465; Güldemann \& Vossen 2000: 99-101), and in some Southern Bantu languages (Niger-Congo family), such as Xhosa, Zulu and Swazi (Herbert 2002), that have long been in contact with Khoisan languages.

There is no reason to believe that all the people whom the navigators met during the first two centuries of sporadic contact on the shores of South Africa and Namibia (Raven-Hart 1967) were speakers of one and the same language. However, there are some reasons to think that the numerous pastoralist communities stretching from Algoa Bay, on the Indian Ocean coast, to the Orange River (and possibly further north), on the Atlantic Ocean coast, which are known to have formed, in the 17th century, a long chain of genealogically- and politicallyrelated groups of cattle and sheep herders, were speakers of very close varieties of the same language (Elphick 1977: 10, passim). These people used to call themselves Khoekhoe, an auto-ethnonym formed on the nominal stem Khoe, 'person, human being' preceded by the adjectiveally-used root in the sense of 'human', meaning 'true human being'. From the time the Dutch established a colony at the Cape of Good Hope in 1652, to the disintegration of their societies and their almost complete physical disappearance due to epidemics by the beginning of the following century (Elphick 1977), the Khoekhoe were in very close contact with the settlers and all the travelers calling at the Cape while on their way to the East Indies. This situation, though very short in time, explains the existence of a significant amount of written material on the Khoekhoe living in the vicinity of the Cape in the 17th century and at the beginning of the 18th (Raven-Hart 1971; Fauvelle-Aymar 2002). As for the last part of the 18th century, the process of acculturation of the remaining Khoekhoe groups or individuals is not very well documented, mainly due to the fact that this occurred on the frontier zone, far from the view of officials and foreign callers. Late 18th century travelers did, however, meet remnants of very distant Khoekhoe groups, but generally left but very scarce information.

Not all Khoekhoe societies lived along South African coastal plains within reach of 17th and 18th century Cape colony. By the beginning of the 19th century, some herding groups (such as the Einiqua, Namaqua, and the Korana or !Kora) were found living inland in the middle Orange River valley. Other Namaqua (known as Great Namaqua) groups were also found established in Southern Namibia in the 19th century. How all these Khoekhoe groups were historically related with the Cape Khoekhoe is subject to debate.

Namibia is the only place where a Khoekhoe dialect (namely Nama/Damara or Khoekhoegowab) is still spoken today. Works by specialists are 
available in this regard: dictionaries (Krönlein \& Rust 1969; Haacke \& Eiseb 2002); studies on the phonology (Beach 1938), grammar (Hagman 1977) and tonology (Haacke 1999) of Namibia Khoekhoe. Apart from Korana, which was summarily described just before it became extinct (Wuras 1920; Meinhof 1930; Engelbrecht 1936) — and which some specialists consider a different language, no other Khoekhoe dialect has been studied to a significant extent. Particularly striking is the discrepancy between the very few studies of Cape Khoekhoe and the fair quantity of linguistic material left by travelers and settlers: a work such as that of Peter Kolbe (1719), for instance, is still considerably overlooked even though it contains a list of hundreds of Khoekhoe words translated into German and Latin, to say nothing of its first-range historical and ethnographical value. The very small number of copies of this book available in public libraries, the fact that no modern edition of the book exists, in addition to the fact that it was written in German and that the translations available in other languages (French, English and Dutch) are considerably biased, explain for a large part why this work is underused or misused. As for modern studies on the Cape Khoekhoe language, one must mention G.S. Nienaber's Hottentots (1963), which is an Afrikaans/Khoekhoe dictionary referring, under each entry, to all the relevant historical sources. Although very useful, this work suffers from several flaws. First, no critical analysis was made of the published evidence, leading the author to use unchecked versions (Kolbe's book, for instance, is used in its Dutch edition of 1727 , displaying huge divergences with the original text, concerning the way to render the clicks in particular). Second, since there is a great divergence in the written forms found among the sources, Cape Khoekhoe words are generally reconstructed after the Nama or Korana languages, especially in the determining of clicks. Almost necessarily, such a method artificially increases the relatedness between various dialects and conceals possible regular sound shifts, thus seriously minimizing its value both on linguistic and on historical grounds. One can also suspect that Christopher Ehret's lexicostatistical and glotto-chronological studies of Khoekhoe dialects/languages (eg. Ehret 1982) are based on Nienaber's work, or possibly on a narrower sample of equally-biased sources, such as Kolbe's Dutch edition. Thus, apart from the question of the intrinsic validity of the method used, one can wonder whether Ehret's historical hypothesis shares the same flaws as the sources on which it is based.

These and other examples should be strong incentives not to go too far into comparative linguistics on Khoekhoe language, as long as the basic needs of properly edited linguistic materials are not fulfilled (Fodor 1975: 157-161 et pas- 
sim). The following is a first attempt by the author, who is not a linguist but a historian, to provide linguists with such material.

The Brenthurst Library in Johannesburg (South Africa) holds the papers of Colonel Robert Jacob Gordon (1743-1795), the once famous commandant of the Dutch Vereenigde Oost-Indische Compagnie garrison of the colony of the Cape of Good Hope.' During his sojourn in the Cape (1777-1795), Gordon made several discovery trips inland and behind the frontier of the Colony. ${ }^{2} \mathrm{He}$ corresponded with philosophers and naturalists in Europe, sending them written descriptions and specimens of minerals, plants or animals, and was the main informant of many foreign travelers of the time. But, due to the fact that he committed suicide when the British took over the Cape in 1795, his extensive travel diaries and other papers, some of which were obviously being prepared for publication, remained unpublished and their importance remained virtually unknown. Brought back to England by his widow, Gordon's papers passed through various hands in the course of the 19th century, until the collection was finally divided in two parts. The drawings and maps, consisting of six volumes collectively known as the "Gordon Atlas", were bought in 1914 by publisher Martinus Nijhoff (The Hague, Netherlands) and were afterwards filed at the Rijksprentencabinet in Amsterdam (Raper \& Boucher 1988: 11-13). Despite their being of considerable interest, they remain for the most part unpublished. An incomplete photocopy of the maps and drawings is said to have once been available at the Museum Africa (formerly Africana Museum) in Johannesburg (H.G.O. 1948) but has not been recovered; another partial photocopy of the maps and drawings is hosted in the Cape Archives. ${ }^{3}$ The other papers of the original collection of manuscripts were thought to be lost until 1964 when they re-appeared in the Staffordshire County Record Office (England). They were purchased in 1979 by the Brenthurst Library in Johannesburg, where they are registered under the number MS 107/1 to MS 107/18. A photocopy of the travel diaries (known as "Gordon's Dagboek") is

1 Robert Jacob Gordon's grandfather had come to the Netherlands from Scotland, hence Gordon's Scottish name. But Gordon was all through his life a loyal Dutch soldier attached to the family of the Prince of Orange. That he may have displayed favorable feelings towards the Orangists and the British at the time of the French Revolution and invasion of the Netherlands could have placed him in a difficult personal situation by the end of his career, and may have led to his end (see below). On Gordon's life, see Cullinan (1992).

2 Gordon had previously spent ten months at the Cape in 1773-4. It is when back in his homeland that he met the French philosopher Denis Diderot (Cullinan 1989).

3 National Archives of South Africa. Cape Town Archives Repository. M1/138 to M1/147, $\mathrm{M} 1 / 1105$ to M1/1132, M1/3201 to M1/3210, AG7146/1 to AG7146/223B. 
held in the Cape Archives. ${ }^{4}$ Almost all papers left by Gordon are written in Dutch, but some documents (most probably intended to be transmitted to European correspondents) are written in English or in French.

A number of researchers have been working on these papers for the last three decades or so, leading to the publication of a meticulously-edited English translation of the four travel diaries of Gordon in South Africa (Raper \& Boucher 1988), ${ }^{5}$ portions of his letter to Hendrik Fagel, a prominent state clerk in the house of Orange (Smith \& Pheiffer 1994) ${ }^{6}$ and a draft essay entitled in French "Particularités relatives à quelques hordes hottentottes" (Particular information on some Hottentot hordes) (Smith \& Pheiffer 1992). ${ }^{7}$ A considerable amount of work remains to be done on these archives, which are of prime interest for the history of the Cape colony, the history of natural sciences and the ethnography of Southern African peoples, of whom Gordon was a very acute and sympathetic observer.

The essay entitled "Particularités relatives à quelques hordes hottentottes" consists of field notes that were then intended for publication at a later stage, which came to nothing. But since some were apparently incorporated into the diary of Gordon's third or fourth journey (leading him along the Orange River that was then the border of the Cape colony - and is today the border between South Africa and Namibia) between June 1779 and January 1780, one can ascribe these observations to that time, that area (today Northern Cape) and the people who then inhabited that area, namely the "Little"-Namaqua ${ }^{8}$ (Smith \& Pheiffer 1992: 5-6). The very short wordlist contained among the same set of papers and referring to the name of the months can thus be attributed to the same people (Smith \& Pheiffer 1992: 40-41).

4 National Archives of South Africa. Cape Town Archives Repository. VC 592 to VC 598.

5 Another translation (by Patrick Cullinan) of Gordon's travel diaries, accompanied by the Dutch transcription, has been made available on the Internet, at:

http://web.uct.ac.za/depts/age/people/Gordon/.

6 The unabridged English translation by R.H. Pheiffer (without editor's notes) is to be found on the Internet, same website:

http://web.ucu.ac.za/depts/age/people/Gordon/gordon_letter.htm (accessed in July 2005).

7 Edition of the Dutch with an English translation annotated with ethnographical comments. The titles given to the folders are said not to be from Gordon's hand, but rather from his wife's, who was born in Switzerland, and who probably tried to put the papers in order after his death.

8 As opposed to the "Great"-Namaqua of Great Namaqualand in Namibia. 
There is plenty of other linguistic material in the Gordon papers. Most noticeable is a blue folder entitled (again in French) "Collection de mots des divers langages de l'Afrique méridionale" (Collection of words from various languages of Southern Africa). ${ }^{9}$ It contains eleven documents that, for the most part, consist of lists of Bantu words from South African, Angolan and Mozambican languages, with their translation into Dutch. ${ }^{10}$ Among these documents are also found four pieces containing material in Khoekhoe languages. They are (in archival order):

- MS 107/10/1 [hereafter list A]. 1 sheet, width $210 \times$ height 330 $\mathrm{mm}$. Recto. No title. From the general aspect of these notes, one may infer, without any definitive evidence, that they are original field notes. From the comparison between the names of the two Oliphants (Afrikaans: Olifants) Rivers (probably the one that flows into the Atlantic Ocean $250 \mathrm{~km}$ north of Cape Town and the one that runs in the Little Karoo) (see Raper 2004: 288 ), and from the mention of the Gouritz River (that flows into the Indian Ocean to the west of the modern town of Mossel Bay), it can be assumed that this short collection of words was gathered during a voyage when he visited both areas, possibly during the second voyage between August 1778 and January 1779 (Raper \& Boucher 1988: 182). In any case, this list is likely to be ascribed to the period between October 1777 and January 1780 , for the accounts of the three trips made during this short period display the same way of rendering clicks with diacritical signs upon consonants. Except for the name of the North Olifants River, the list A is composed of river names and other (apparently local) information concerning the Little Karoo.

- MS 107/10/5 [hereafter list B]. 1 sheet, w275 × h432. Recto. Title: "Enige hottentots woorden" (Some Hottentot words). Given the neat

9 Brenthurst Library, Gordon papers. MS 107/10.

${ }^{10}$ MS 107/10/2 (A few scattered notes on "Caffers" language); MS 107/10/3 (Xhosa wordlist? Various notes and calculations); MS 107/10/4 (Xhosa wordlist); MS 107/10/6 (two lists of Angola/Congo languages: 1. "Naam van het land van een swarte slaaf die te Loando St. Paúlo door de Portugesen aan de Fransen verkogt is. Lakombo was syn eigen naam en syn vaders naam Kongo en syn moeders Dampi. Syn land hiete Quacombo...". 2. "Naam van het land van myn grote swarte Cúpido Gakinge door syn anders genaamt"); MS 107/10/8 (Information on the Maratjsa, "een sort van Mackúas", or "swarte Caffers" who live around the tropic of Capricorn. Wordlist of the "Maratjsa Caffer taal"); MS 107/10/9 ("Madagascar taal" apparently collected from several Malagasy slaves); MS 107/10/11 (Tswana wordlist: "Moetjsonana taal. Die de Hottentotten Briquás noemen"). 
aspect of the document and of the actual writing, it cannot be considered as field notes but as a carefully re-written document. Minor additions (including the title) and corrections, possibly not from the same hand, have been made with a different (green) ink that does not alter significantly the reading. No external element makes it possible to attribute the collected words to any area in particular or to any period of time spent by Gordon in the field. However, the use of a completely different system to render the clicks (by a superscript $t$ before some consonants) is a strong argument toward a different period of time, rather later than the previous one. This new system is not used in Gordon's traveling accounts, but it can ex silentio be considered coeval with his fourth voyage between November 1785 and March 1786, for he does not make use of the previous click system in his traveling account. This fourth and last voyage to the border of the Colony took Gordon to Algoa Bay through the great Karoo and the Baviaanskloof, and then back to Cape Town along the coast (Raper \& Boucher 1988: 386). One can also notice that the word Toe ('Dog') is only attested in Eastern Khoekhoe (Nienaber 1963: 308), but linguists are left to decide whether this and other possible clues are decisive or not.

- MS 107/10/7 [hereafter list C]. 1 sheet, w383 $\times$ h225. Recto. No title. As for list A, it appears to be field notes recorded between 1777 and 1780 (but not on the same paper nor with the same ink). From the name of a Seacow River, which could be the Seekoei River - tributary of the Orange river visited several times by Gordon — but which in fact is the Dutch translation of a Khoekhoe name corresponding to the Bushmans River (which flows into the Indian Ocean to the East of Algoa Bay), it can be proposed that the entire list was collected when Gordon was present in the lower valley of this river for the first time in January 1778 (Raper \& Boucher 1982: $140 \mathrm{sq}$ ). On that occasion he met with a Khoekhoe chief named Ruiter, "who has Gounaquas and Bastard Hottentots under him" (Raper \& Boucher 1982: 140). Gordon spent some time drinking sour milk with the chief, who provided him with a guide to take him to the sea. Since it is likely that it is from this guide that Gordon collected the Khoekhoe name of the river (Raper \& Boucher 1982: 141), the same can be asserted for the rest of the list. If this is so, this piece of Khoekhoe vocabulary is certainly one of the most informative we have concerning the Gonaqua/Hoengeiqua of the area. The list is not a word list but rather a list of sentences. 
— MS 107/10/10 [hereafter list D]. 1 sheet, w206 $\times$ h243. Recto. No title. Fieldnotes. There is very little internal or external evidence to date this document, except the fact that Gordon again uses the superscript $t$ to note clicks, which could be an argument to attribute this list to the same area and time as list B.

In the following transcription, Gordon's spelling, punctuation, use of small or capital letters, underlining, and use of diacritical signs have been scrupulously respected. Idem for the order of Khoekhoe/Dutch entries. Strikeout represents Gordon crossing letters or words out. The sign / (slash) is used here to indicate that words presumably part of one sentence or one comprehensive set of words are not placed on the same line in the manuscript. My interventions are limited to the placing of words in two columns when it proved possible and useful. I have also used italic font to signify Khoekhoe words or sentences. Wherever it proved necessary to restitute part of a word or to mention alteration or uncertain reading, I did it between square brackets [...]. In the footnotes, I give the English translation of the Dutch words and various other comments, and I use the sign $* * *$ to replace any Khoekhoe word which does not need to be repeated.

\section{List A \\ Little Karoo Khoekhoe? ca. 1777-80}

Ćara Ćamma / noord / Oliphants / ivivier $^{11}$

Sneirwig, / sort van / bosjes ${ }^{12}$

Oost Oliphant kìacas ${ }^{13}$

Nari; bloem ook g̀a. / ñuriqua ${ }^{14}$

verkeerde valey ${ }^{15}$

11 Previously written Ćàra. North Olifants River (today Olifantsrivier), as opposed to the East Olifants River (see below), is probably the one flowing northward from Tulbagh to Papendorp in the Western Cape. Raper (2004: 288) indicates that the Khoekhoe name of that river was Tharakkama or Trakamma, which is consistent with the name given by Gordon.

Sneirwig, sort of bushes. Sneirwig: reading uncertain. Bosjes: $b$ superimposed on a $g$.

${ }^{13}$ East Olifants. Obviously the modern Olifants River that becomes the Gourits River and flows in the Indian Ocean near Mossel Bay.

$* * *$ flower, also ***.

Wrong valley. 
keina ćamma of mooy water ${ }^{16}$

en $k\left[\ldots{ }^{17}\right]$ ćamma is Oliphan[ts] / riv[ier] by gourits. ${ }^{18}$

Ćobeeb hexerivier. ${ }^{19}$

het casteel hiet / kúi keip of klipkraal. ${ }^{20}$

Sonder klap ${ }^{21}$

$\underline{\text { Toa Togoú de naam van Captein kees vader. besokend }}{ }^{22}$

Sÿn goed sal niet vergaan. ${ }^{23}$

hei ónna sonder naams ${ }^{24}$

is de naam van Captein kees ${ }^{25}$

Camteep was ook myn naam ${ }^{26}$

hiet pluimdrager ${ }^{27}$

\section{List B \\ Eastern Cape Khoekhoe? ca. 1785-6?}

Soré

${ }^{t}$ Caan

${ }^{t}$ Ca caan

hoeri / $\mathrm{O}^{t} \mathrm{Camma}$
$\operatorname{Zon}^{28}$

$\operatorname{Maan}^{29}$

Sterren $^{30}$

Zeewater $^{31}$

$16 * * *$ or nice water.

${ }^{17}$ Writing unclear: possibly kwúni.

18 And *** is Olifants River near the Gourits.

19 Hex River, in the region of Worcester (Western Cape). See Raper (2004: 136).

20 The castle [of Good Hope?] is called $* * *$ or stone kraal.

${ }^{21}$ Without click. Refers probably to the pronunciation of the words below, which are underlined.

$22 * * *$ the name of Captain Kees' father. Visited.

${ }^{23}$ His goods will not disappear.

$24 * * *$ without name.

25 Is the name of Captain Kees. Probably follows the name above.

26 Was also my name.

27 The feathers-bearer. Obvious translation of the above word; compare to nama !ami, !ammi, 'feather' (Nienaber 1963: 493 'veer'; Haacke \& Eiseb 2002). This name is likely to refer to Gordon's military hat.

Sun.

${ }^{29}$ Moon (= month?).

30 Stars.

${ }^{31}$ Sea water. Hoeri is a later addition. 
Goedi

${ }^{t}$ Caune

${ }^{t} k \tilde{u} i$

Tam

${ }^{t}$ Nonà

Hakka

Gissi

${ }^{t}$ Kwaab

${ }^{t} \mathrm{Nabab}$

Jees-Owa

Héba ha mi com

Sase qũoi qũoi / mienqua kanje

Areti ${ }^{t} j a$

Sase ${ }^{t} \mathrm{ca}^{t}$ couha

'za am'li he Sats

Tiri ${ }^{t} k a i$

Goere

${ }^{t} Q \tilde{u} o \tilde{u} q \tilde{u} e$
Schaap $^{32}$

$\mathrm{Lam}^{33}$

Een $^{34}$

Twee ${ }^{35}$

Drie $^{36}$

Vier $^{37}$

V̈̈ff Tien ${ }^{38}$

Oliphant $^{39}$

Rinoster $^{40}$

God $^{41}$

Spreeken $^{42}$

Hottentots spreeken ${ }^{43}$

Gÿ Zijt mÿn vriend ${ }^{44}$

Wilt gÿ drinken ${ }^{45}$

hoe vaart $g \ddot{y}^{46}$

Ik ben wel ${ }^{47}$

$\operatorname{Boog}^{48}$

$\mathrm{Man}^{49}$

32 Sheep.

33 Lamb. Possible dot on $\mathrm{u}$.

${ }^{34}$ One. Gordon had previously written ' $g \tilde{u} i$.

35 Two. Gordon had previously written Cam.

36 Three.

${ }^{37}$ Four.

38 Ten. Gordon had previously written Gisi (reading uncertain).

39 Elephant.

${ }^{40}$ Rhinoceros.

41 God.

42 Speak. Gordon had previously written Héwa.

43 Speak Hottentot.

${ }^{44}$ You are my friend. Gordon had previously written ${ }^{t} d a$.

45 Will you drink.

${ }^{46}$ How are you.

47 I am well.

48 Bow.

${ }^{49}$ Man. 
Tiri 'arun'a

Sase

Tiri ${ }^{t}$ can ${ }^{t}$ camme ${ }^{t} \mathrm{ca}$

${ }^{t}$ Caini awei ${ }^{t}$ camma

Ham 'cobebe ${ }^{t}$ cobe / ha haha, 'noe casi

${ }^{t}$ Cobe Licanse

Hebati robe a / hala, hammosfi

${ }^{t}$ Coebe ahaha

tTikkúisł

${ }^{t}$ Cain $\mathrm{si}^{t} \mathrm{ca}{ }^{t}$ cali ${ }^{t}$ camma

Jesowa ${ }^{t}$ cam Siszeme/ ${ }^{t}$ conge

Hese ${ }^{t}$ kein ${ }^{t}$ coeba

Hese ${ }^{t}$ kein tite tite ${ }^{t}$ Coeba

Toekei

Tera|kuis

${ }^{t}$ Quouque

$B i^{t} a$

Mouqua
Ik heb honger ${ }^{50}$

$\mathrm{G} \ddot{y}^{51}$

Ik heb dorst ${ }^{52}$

Dat is lekker ${ }^{53}$

een liedje $\mathrm{e}^{54}$

Mÿn land is vet ${ }^{55}$

halen

Waar is ũw land ${ }^{56}$

myn vroũw keus vrouw ook tera of tra kuis ${ }^{57}$

Ik drink ũ gesondheÿd ${ }^{58}$

God zÿ met $\tilde{u}^{59}$

$T$ 'is mooÿ weer van dag ${ }^{60}$

Geen goed weer ${ }^{61}$

Regen $^{62}$

Vroũw $^{63}$

$\mathrm{Man}^{64}$

Het Hooft ${ }^{65}$

Oogen $^{66}$

${ }^{50}$ I am hungry.

51 You.

52 I am thirsty.

${ }^{53}$ That is nice.

${ }^{54}$ A song.

55 My land is fat.

56 Where is your land.

$57 * * *$ my wife, ${ }^{* * *}$ wife, also *** or ***. Gordon had previously written Tikois.

${ }^{58}$ I drink (to) your health.

${ }^{59}$ God is with you.

${ }^{60}$ It's fine weather today.

${ }^{61}$ Not fine weather.

${ }^{62}$ Rain (noun and verb).

63 Woman, wife.

64 Man.

65 The head.

66 Eyes. 


\begin{tabular}{|c|c|}
\hline${ }^{t}$ Nanqua & Ooren $^{67}$ \\
\hline hoeri ${ }^{t} \mathrm{kei}$ & $\mathrm{Zee}^{68}$ \\
\hline${ }^{t} \mathrm{Cam}{ }^{t} n a$ & Mond $^{69}$ \\
\hline${ }^{t}$ Coong & Tanden ${ }^{70}$ \\
\hline${ }^{t} a$ & Voeten $^{71}$ \\
\hline${ }^{t}$ oenqua & hand $^{72}$ \\
\hline Tora & Schamelheyd der Mans ${ }^{73}$ \\
\hline${ }^{t} N e u b$ & Schamelheyd van een / vrouw ${ }^{74}$ \\
\hline Tamma & Borst $^{75}$ \\
\hline Samma & Prammen $^{76}$ \\
\hline Domma & $\mathrm{Keel}^{77}$ \\
\hline${ }^{t}$ Gouti & Singen $^{78}$ \\
\hline${ }^{t}$ Nour à & Knife nes ${ }^{79}$ \\
\hline${ }^{t}$ Camseũwè & $\mathrm{T}^{\prime}$ is waar ${ }^{80}$ \\
\hline $\operatorname{aaan}^{t} a$ & $\mathrm{Ja}^{81}$ \\
\hline aaan te & Neen $^{82}$ \\
\hline Toe & $\operatorname{dog}^{83}$ \\
\hline On ${ }^{t}$ [Sahs $]^{t}$ onha maré & hoe is üw naam ${ }^{84}$ \\
\hline Cour-Cour & hen hoen ${ }^{85}$ \\
\hline
\end{tabular}

${ }^{67}$ Ears.

${ }^{68}$ Sea. Gordon had previously written goeri.

${ }^{69}$ Mouth.

70 Teeth.

71 Feet.

${ }^{72}$ Hand.

${ }^{73}$ Men genitals (literally: shamefulness).

${ }^{74}$ Genitals of a woman (literally: shamefulness).

${ }^{75}$ Breast, chest.

76 (Woman) Breasts.

77 Throat.

78 Sing.

${ }^{79}$ Sic: $m e s$. Knife. Note English word used at first.

${ }^{80}$ It's true.

${ }^{81}$ Yes. Possibly dots above second and third $a$ (reading uncertain); possibly aaan ta.

${ }^{82}$ No.

83 Dog. Note English word used instead of Dutch Hond. Compare with tu, tuna in Eastern Cape Khoekhoe (Nienaber 1963: 308, "Hond IV").

What is your name? 


\section{List C \\ Eastern Cape Khoekhoe (Gonaqua/Hoengeiqua)? 1778?}

Nantroo.

G̀oandi $\grave{C} o b i$

Tauwn

demaatse ${ }^{89}$ ho keúi

de éi saatse ha be

de éi saatse co hema ba

Ċamoe

Kauwgha

Boo $\left[{ }^{95}\right]$ éss

dieti tse na t́souwa kei

dieḱa hema tse nati mi

Goinka tse c̄aa tau ha

Tabaca ha tse 'taú ha
Landrost $^{86}$

ganse valey ${ }^{87}$

fontein $^{88}$

waar leg je nú 90

wanneer ga je weer weg ${ }^{91}$

wanneer ben je hier gekomen ${ }^{92}$

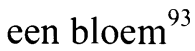

hiet zeekoeirivier is bosjemans rivier. $^{94}$

hiet de fontein aan bosjesmans riviers mond. ${ }^{96}$

hoe hiet die fontein ${ }^{97}$

waarom seg zÿ so ${ }^{98}$

wil je een glas wÿn hebben ${ }^{99}$

wil je een stúk tabak hebben. ${ }^{100}$

${ }^{85}$ Hen. Notice English word (initially spelled hem) used at first.

${ }^{86}$ Landdrost (magistrate).

${ }^{87}$ Geese valley.

${ }^{88}$ Fountain, spring.

${ }^{89}$ Reading uncertain.

90 Where do you lay (stay) now?

91 When are you going away again?

92 When did you come here?

93 A flower.

$94 * * *$, that is Seacow River, is the Bushmans River. Compare with Caugha, "hippopotamus river" in Raper \& Boucher (1982: 141).

95 One or two letters added, unreadable.

$96 * * *$ is the name of the spring at the Bushmans River mouth.

${ }^{97}$ How is the spring called?

98 Why do they say so?

99 Will you have a glass of wine?

${ }^{100}$ Will you have some tobacco? 
ik heb dat os gehad een os

ik sal een os krÿgen

ik heb een os

ik heb gisteren een os gehad

ik denk dat het waar is

Het is waar

Ik heb van daag geen os

Het is geloogen Jÿ liegt

Ik sal daar na toe gaan

Sal jÿ daar na toe gaan

hoor jÿ mÿ niet

Waarom lag z $\ddot{y}$

Waarom huil zÿ.

Sagjes wat.

Saats keintse keúi tiri go ka ha. ${ }^{101}$

tiri ha goa ho ${ }^{102}$

tirit $^{103}$

koaase ${ }^{104}$ tiri ko $_{\mid}$go ka ha ${ }^{105}$

Camma se ti tiri ei. ${ }^{106}$

Camma saawse 107

he see tiri go ka hátse. ${ }^{108}$

gǹ hoo saatje ma hie owi ${ }^{109}$

tiri ha naatse kon. ${ }^{110}$

Saatse ha naatse kon.

Saatkena tiri nauwte. ${ }^{112}$

die $\left[. .{ }^{113}\right]$ éimatse $\mathrm{kei}^{114}$

die éimatje kyn ${ }^{115}$

Ċaboose. ${ }^{116}$

Je moet daar mooÿ vredig leggen ${ }^{118}$

${ }^{101}$ I have an ox.

${ }^{102}$ I shall receive an ox.

${ }^{103}$ I have an ox.

${ }^{104}$ Previously goaase.

${ }^{105}$ I had an ox yesterday.

${ }^{106}$ I think that it is true. Last Khoekhoe word uncertain.

${ }^{107}$ It is true. Last Khoekhoe word uncertain.

${ }^{108}$ I have no ox today.

${ }^{109}$ You sing.

${ }^{110}$ I shall go there.

${ }^{111}$ Will you go there?

${ }^{112}$ Do not you hear me?

${ }^{113}$ One possible letter unreadable.

${ }^{114}$ Why do they laugh?

${ }^{115}$ Why do they cry?

${ }^{116}$ Slowly! (interjection)

${ }^{117}$ Possibly accent on $\mathrm{k}$.

${ }^{118}$ You must lie very peacefully there (I wish you a very peaceful rest there). 


\section{List D}

Attribution uncertain, ca. 1785-6?

${ }^{t s}$ Kormoutsti $^{119}$
${ }^{t}$ Kwamoutsi ${ }^{121}$
bareb
${ }^{t}$ eip
tabete
${ }^{t}$ camma
${ }^{t}$ ca
arikn ${ }^{128}$
${ }_{\text {issa }}$
ti ${ }^{\text {ts }}$ com ${ }^{t}$ ym
Koĩess
Kõ̃eb
${ }^{t}$ oãm
${ }^{t s}$ tam
gamma
${ }^{t}$ houkha

goeden avond $^{120}$

goeden morgen $^{122}$

brood $^{123}$

vuur $^{124}$

goeden $\operatorname{dag}^{125}$

water $^{126}$

drinken $^{127}$

hond $^{129}$

$\operatorname{mooy}^{130}$

een $\operatorname{man}^{131}$

een vrouw ${ }^{132}$

een $\operatorname{man}^{133}$

hand $^{134}$

mooy weer ${ }^{135}$

leew $^{136}$

een wolf ${ }^{137}$

${ }^{119}$ Letters or uncertain.

${ }^{120}$ Good evening.

${ }^{121}$ Letter $w$ uncertain.

122 Good morning.

123 Bread.

${ }^{124}$ Fire. Last letter of Khoekhoe word uncertain.

${ }^{125}$ Good day. Possibly ${ }^{t}$ abete.

126 Water.

${ }^{127}$ Drink.

${ }^{128}$ Last letter of Khoekhoe word uncertain (but not $u$ ).

${ }^{129}$ Dog.

${ }^{130}$ Nice.

131 A man.

${ }^{132}$ A woman.

133 A man.

${ }^{134}$ Hand.

${ }^{135}$ Nice weather.

${ }^{136}$ Lion.

${ }^{137}$ A wolf (hyena?). 


ha Xatsi ${ }^{t} g a$
g[...]s beep
${ }^{t}$ ei kwakou
danna ka tse he [...]rogadaw
ka tse moe he comma
${ }^{t}$ goukweis

The importance of these lists is obvious. Not only can they document Cape Khoekhoe lexicon and toponymy, but also increase our knowledge on some aspects of the grammar, which was hardly the case for any other Khoekhoe wordlist compiled prior to one century ago. They are also evidence that, contrary to what is sometimes assumed, the Cape Khoekhoe language was still frequently used by the end of the 18th century, not only on the remote border of the colony but also in areas, such as the Little Karoo, that had long been confiscated by white farmers. Possibly, these lists could also help document regional diversity in the Cape Khoekhoe language, and thus give credit or not to the generally-admitted distinction between "Cape Khoekhoe" proper and "East Cape Khoekhoe" (see Kaap vs Oos in Nienaber 1963), or Western, Central and Eastern Cape Khoekhoe (Elphick 1977: passim), which are admittedly purely contextual or arbitrary classifications (eg Elphick 1977: xvii).

Of interest here is the range of special and diacritical signs used by Gordon to render the various influxes and effluxes that make up clicks, and possibly other characteristics of the language. Thus, the tilde $(\sim)$ is mainly used on the vowel $u$, possibly to represent the sound $/ \mathrm{u} /$ in Khoekhoe, in order to differentiate it from the sound /y/ common in Dutch (eg. vuur (fire), /vy:r/). But this use does not appear to be systematic (even in Gordon's Dutch, where it is erratically used), a feeling that is reinforced by the fact that the Khoekhoe word for 'man' appears twice in the list $\mathrm{B}$, once with and once without a tilde on the $u$. The tilde also appears in list $\mathrm{D}$ on the vowels $i$ and $a$, though the alteration introduced is unclear. Similarly, accents are used on certain vowels, but it also remains unclear whether these are used to modify their value or to mark length, nasalization or tone. In two

\footnotetext{
${ }^{138}$ Come here (my) friend.

${ }^{139}$ Animal milk.

${ }^{140}$ Fire making.

${ }^{141}$ Where is the wagon path?

${ }^{142}$ Show me the place.

${ }^{143}$ You are my friend.
} 
cases Gordon seems to use a subscript vertical hyphen that could also mark the tone.

Many systems have been used among travelers and scholars until a more or less standardized system was eventually adopted (e.g. Nienaber 1963: 162-163; Köhler 1981: 472-5). Gordon apparently invented two completely different systems for his own use. The first one, as displayed in lists $\mathrm{A}$ and $\mathrm{C}$ (corresponding to the years 1778-9), makes use of a range of accents placed on the first (or in one case on the second) consonants at the beginning of the words. The combinations

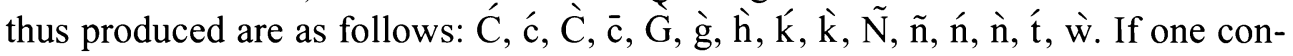
siders that small and upper capitals are possibly insignificant variations and that the accent on $\mathrm{w}$ may be aberrant, we are left with six consonants able to bear accents: C, G, H, K, N and T. The second system, as displayed in lists B and D (corresponding to the year ca. 1785), makes use of a superscript $t\left({ }^{t}\right)$, that, once again, always immediately precedes six possible consonants $(\mathrm{C}, \mathrm{H}, \mathrm{K}, \mathrm{N}, \mathrm{Q}, \mathrm{Z})$. Only $\mathrm{C}$, $\mathrm{H}, \mathrm{K}$ and $\mathrm{N}$ are found in both systems. The superscript $t$ is employed twice before the vowel $e$ (in both cases it refers to the word ' $e i(p)$, 'fire') and once before the vowel a. In one instance, the superscript $t$ is followed by an apostrophe and, in another, the two letters $t s$ are superscript.

After a mere comparison of the word 'water' written in the two systems (lists $\mathrm{A}$ and $\mathrm{B}$ ), one can suggest that the sign $\mathrm{C}^{\prime}$ corresponds to ${ }^{t} \mathrm{C}$ and that both of them are used to mark the click //g (Nama orthography). But only a systematic comparison between the two systems and a sound comparison between the data provided by Gordon's wordlists and other collections of Khoekhoe words could eventually allow reconstructing at least part of the Cape Khoekhoe dialect. Here stops the work of the historian, knowing that he will probably benefit later from the work of the linguist. 


\section{REFERENCES}

Beach, Douglas M. 1938. The Phonetics of the Hottentot Language. Cambridge: W. Heffer \& Sons.

Cullinan, Patrick. 1989. "Robert Jacob Gordon and Denis Diderot: The Hague, 1774". Quarterly Bulletin of the South African Library 43 (4): 146-152.

Cullinan, Patrick. 1992. Robert Jacob Gordon, 1743-1795: The Man and his Travels at the Cape. Cape Town: Struik.

Ehret, Christopher. 1982. "The First Spread of Food Production to Southern Africa", The Archaeological and Linguistic Reconstruction of African History ed. By Christopher Ehret and Merrick Posnansky. Berkeley: University of California Press. Pp. 158-187.

Elphick, Richard. 1977. Kraal and Castle. Khoikhoi and the Founding of White South Africa. New Haven: Yale University Press.

Engelbrecht, Jan A. 1936. The Korana. Cape Town : Maskew Miller.

Fauvelle-Aymar, François-Xavier. 2002. L'invention du Hottentot. Histoire $d u$ regard occidental sur les Khoisan (XVe-XIXe siècle). Paris : Publications de la Sorbonne.

Fodor, István. 1975. Pallas und Andere Afrikanische Vokabularien vor dem 19. Jahrhundert. Ein Beitrag zur Forschungsgeschichte. Hamburg: Helmut Buske.

Greenberg, Joseph. 1966. The Languages of Africa. Bloomington: Indiana University.

Güldemann, Tom \& Vossen, Rainer. 2000. "Khoisan". African Languages: An introduction, ed. by Bernd Heine and Derek Nurse. Cambridge: Cambridge University Press. Pp. 99-122.

Haacke, Wilfrid H.G. 1999. The Tonology of Khoekhoe (Nama/Damara). Cologne: Rüdiger Köppe. 
Haacke, Wilfrid H.G. \& Eiseb Eliphas 2002. A Khoekhoegowab Dictionary with an English-Khoekhoegowab Index. Windhoek: Gamsberg Macmillan.

Hagman, Roy S. 1977. Nama Hottentot Grammar. Bloomington: Indiana University.

Herbert, Robert K. 2002. "The Sociohistory of Clicks in Southern Bantu". Language in South Africa, ed. by Rajend Mesthrie. Cambridge: Cambridge University Press.

Köhler, Oswin. 1981. "Les langues khoisan”, Les langues dans le monde ancien et moderne, ed. by Jean Perrot. Paris : Éditions du CNRS. Vol. 1, pp. 457-615.

Kolbe, Peter. 1719. Caput Bonae Spei Hodiernum, das ist Vollständige Beschreibung des Africanischen Vorgebürges der Guten Hofnung. Nuremberg: Conrad Monath.

Krönlein, Johann G. \& Rust F. 1969. Nama Wörterbuch. Pietermaritzburg: University of Natal Press.

Meinhof, Carl. 1930. Der Koranadialekt des Hottentottischen. Berlin: Dietrich Reimer.

Nienaber, Gabriel S. 1963. Hottentots. Pretoria: J.L. Van Schaik Beperk.

O.[...], H.G. 1948. "The Gordon Drawings". Africana Notes and Records VI (1): 17-19.

Raper, Peter E. 2004. New Dictionary of South African Place Names. Johannesburg \& Cape Town: Jonathan Ball Publishers.

Raper, Peter E. \& Boucher Maurice. 1988. Robert Jacob Gordon: Cape Travels, 1777 to 1786. Johannesburg: Brenthurst Press, 2 vols.

Raven-Hart, Roger. 1967. Before Van Riebeeck. Callers at South Africa from 1488 to 1652. Cape Town: Struik. 
Raven-Hart, Roger. 1971. Cape Good Hope 1652-1702: The First Fifty Years of Dutch Colonisation as Seen by Callers. Cape Town: A.A. Balkema, 2 vols.

Smith, Andrew B. \& Pheiffer Roy H. 1992. "Col. Robert Jacob Gordon's Notes on the Khoikhoi 1779-80". Annals of the South African Cultural History Museum 5 (1): 1-56.

Smith, Andrew B. \& Pheiffer Roy H. 1994. "Letter from Robert Jacob Gordon to Hendrik Fagel, 1779". Brenthurst Archives 1 (2): 29-46.

Wuras, C.F. (ed. by Walther Bourquin). 1920. Vokabular der Korana-Sprache. Berlin: Dietrich Reimer.

French Institute of South Africa

PO Box 542

Newtown 2113 Johannesburg

Republic of South Africa

francois-xavier@ifas.org.za [received February 28, 2006 accepted April 6, 2006] 